\title{
AUTHENTIC ASSESSMENT: A REAL LIFE APPROACH TO WRITING SKILL DEVELOPMENT
}

Thuong Thi Kim Nguyen ${ }^{1}$ Huyen Minh Phan ${ }^{2}$

${ }^{1}$ Faculty of International Training, Thai Nguyen University of Technology, Thainguyen, Vietnam

${ }^{2}$ Division of English, University of Economics and Business Administration, Thainguyen, Vietnam

*Corresponding Author: Thuong Thi Kim Nguyen

${ }^{1}$ Corresponding Author Email: nguyenthikimthuong@tnut.edu.vn

Article Received: 06-02-20 Accepted: 29-02-20 Published: 05-03-20

Licensing Details: Author retains the right of this article. The article is distributed under the terms of the Creative Commons Attribution-NonCommercial 4.0 License

(http://www.creativecommons.org/licences/by-nc/4.0/) which permits non-commercial use, reproduction and distribution of the work without further permission provided the original work is attributed as specified on the Journal open access page.

\section{ABSTRACT}

Since assessment is an indispensable part of education, curriculum makers, educators and teachers have engaged in an ongoing discussion of how to address student performance. A variety of assessments including both short-term and long-term ones can be applied during or at the end of the learning process. Among such types, authentic assessment is a prominent approach. This paper is going to advocate authentic assessments as it fosters students' growth and teachers' pedagogical strategies. In addition, it helps to reach the goals of educational practices through the authenticity of equity and innovation when students actively seek their own ways to appreciate what they have learnt. Particularly, in a writing skills class, learners can take this opportunity to improve step by step their own proficiency in the use of written words. The paper, hence, discusses how authentic assessment can be applied to develop college students' writing through classroom observation and a set of semi-structured interviews. The result of the study revealed that using authentic assessment is an effective strategy for enhancing students' interest in writing process and writing task fulfillment. Students would find it easier to become skillful writers at their English levels. The study, therefore, recommends more uses of authentic assessment in teaching writing skills as well as in teaching and learning the English language in general.

Keywords: Test, Authentic, Assessment, Writing, Development, Approach 


\section{INTRODUCTION}

Most teachers are busy at the end of the semester grading students' written tests, calculating their overall scores, and reporting or posting their final evaluations on the university website. All the information should be highly accurate, but the dilemma is that whether such numbers and types of assessments would reveal precisely the students' capacities or not. What did the students value in a course? Such a question could hardly be answered. A teacher may feel rather stressful because, to some extent, the accountability of teaching is judged based on such percentages of success or failure. Do all the teachers and students join an educational journey and have to finish it with a number of scores? So what should be a real motive for teaching and learning?

Some of the students, who engaged in learning activities enthusiastically, got shocked when they did not get the scores they expected. Others were distressed after knowing that they failed the English subject for the first, second, or third times.

How do we value teaching and learning in education without a collection of data from multiple-choice tests? Perspectives from positivism, initiated by the French philosopher Auguste Comte, support experimental evaluations in scientific methods and notice the truth for understanding phenomena in the world (Moon, 2014). However, when being applied in educational achievement, a testing system or experimentation of assessment following positivism does not reflect multidimensional expressions of human capacities. The benefits of assessing teaching and students' learning are undeniable. Yet, only by pushing students to do well on tests such as multiple choices and written forms is not always the right way of supporting students' growth. There should be better ways to understand the students' needs and help them grow rather than making conclusions about their high or low-level achievement.

As Dr. Suneetha (2014) claimed, "In order to be effective, educational reforms must be tied to the development of an enhanced curriculum that incorporates authentic assessment practices" (p.1). This type of assessment has become popular in some areas of academic subjects. It helps to increase the authenticity of evaluation and students' motivation in performing their tasks in real life contexts (Wiggins, 1990; Puppin, 2007). In other words, authentic assessment can be an approach that the teacher uses to examine his/her students' knowledge and encourage them to apply what they have learned in authentic settings. Students would not be much worried about the final result as they have various, even enjoyable, ways to express their understanding of lessons. Brown (2004) proposed six types of authentic assessment: performance assessment, portfolio assessment, self-assessment, journal, conference and interview, and teacher observation.

In English language teaching, Idham et al. (2015) emphasizes that learning should meet students' need so that they would be able to apply their knowledge into their own lives. Thus, final outcome, or final evaluation, accordingly encompasses authenticity which, as Gulikers (2006) refines, involves authentic task, physical context, social context, assessment result, and assessment criteria. Teaching productive skills, like writing skills, should embrace those crucial factors. Indeed, helping learners to be competent at writing is a challenging task for teachers of English as this requires effective instructions and long endeavor (Aziz \& Yusoff, 2016; Barkaoui, 2007). 
Hence, this paper not only advocates authentic assessment in education but also offers English teachers viable strategies in writing skill classes. The study aims to reach the goal of constructive pedagogy that leads language learners to a real world of experience and application. Writing would, no longer, be a difficult subject; instead, it would be an opportunity for students to express their inspiration in papers through their favorite topics. Teachers' assessment would correlate with students' interests and unique capacities; consequently, the final results, like scores or critical evaluations, reveal both successful teaching and learning outcome.

The main research question that guides the study is:

How does authentic assessment affect students' writing skill development?

\section{LITERATURE REVIEW}

In America, since the legislation of No Child Left Behind came into effect, teachers and students endure the pressure of mandated standardized tests that change what to teach, how to teach, and how to know students' mastery (Brown \& Knowles, 2007). The Common Core State Standards, according to Noguera (2013), fail to reinvent education as they ignore other factors such as poverty which affects students' academic achievement. When computer-based exams only place students at the center of scoring on multiple, given choices, authentic measures, as Wiggins (1993) asserted, focus on "engaging and worthy problems or questions of importance, in which students must use knowledge to fashion performances effectively and creatively" (p. 229).

For many years since the era of school reforms started, educators and teachers have been looking for alternatives to standardized tests. Authentic assessment was born with the demands of viable educational practices in terms of student-centered pedagogy, and real life approach of teaching and learning. In other words, authentic assessment serves to reach the goals of education as it supports cognitive development, stimulates learning autonomy and advocates the authenticity of equity and innovation in education.

Swaffield (2011) defined that "authentic assessment refers to the assessment of learning that is conducted through 'real world' tasks requiring students to demonstrate their knowledge and skills in meaningful contexts" (p. 434). For example, students report the findings of their research, submit an article or short story for publication, or create an art product. In some cases, authentic assessment is associated with performance assessment when students present knowledge in the form of a performance task.

First of all, authentic assessment pertains to cognitive theories that specify the mental components and the process of knowledge acquisition (Eryaman \& Gence, 2010). Regarding brain-based learning, Jensen (1996) emphasized that "we need to allow for more variety and reality in our learning contexts" (p. 167). He elucidated scientific evidence of mental functions that the brain is sensitive to emotional changes and problem-solving issues. The limbic system helps us to decide which content is essential and the cerebrum, or neocortex, enables us to dissect different meanings (Jensen, 1996). Thus, when leaning activities are more connected with personal interests, students will find it easier to get the desired knowledge. 
Challenging tasks also make the brains work better as students can reach the level of critical thinking and acquire problem-solving skills. This analysis is consistent with Newmann and Archbald's (1992) proposal of authentic achievement that is "to cultivate the kind of higherorder thinking and problem-solving capacities useful both to individuals and to the society. The mastery gained in school is likely to transfer more readily to life beyond school" (as cited in Cumming \& Maxwell, 1999, p. 179). Assessment, therefore, should be accurate or genuine for students to obtain authentic achievement.

With his renowned theory of "Multiple Intelligences," Gardner (1999) focused on "the determination of which intelligence is favored when an individual has a choice" (p. 31). This idea put forth changes in curriculum and assessment that are compatible with students' strengths and weaknesses. Gardner strongly recommended the report of the portfolio that describes a student's intellectual process including progress, efforts or some needed supports for better performance. In this sense, assessment closely relates to real life situations and connects school with parents and community.

Secondly, authentic assessment encourages learner's autonomy through self-awareness and self-reflection. Education is crucial for a person to be able to live and work meaningfully. Hence, learning is not ended with the completion of different evaluations. Knowledge and skills presented at school should go beyond institutions and transform into a treasure that learners possess during their later lives. With appropriate types of authentic tasks, students become aware of their educational targets and strive to reach their expected destinations.

Combining Heidegger's concept of "being-in-the-world", Thuy and Gloria (2013) recommended that authentic assessment stimulates students "to challenge taken-for-granted assumptions, while promoting reflexivity about their own ways of knowing, acting and being" (p. 10). Accordingly, assessment not only helps students know about their actual abilities but also empowers them in the mode of being fully human. Moreover, it urges students to reexamine their prior knowledge and construct their new ways of understanding. This action, as similarly defined in constructivist theory, is an active construction of meanings from experience (Eryaman \& Gence, 2010).

Today the application of technology can help to create the contexts of authentic experience on which students base to get deep meanings through analytical comprehension. A rubric is another useful tool for evaluating students' capacities, as students can get involved in the process of assessment. Ashford-Rowe, Herrington and Brown (2014) propose that metacognition including critical reflection and self-evaluation should be a component of authentic assessment. When students have opportunities to rethink what they think, they would value the results of evaluation instead of worrying about high or low scores.

Hence, Dewey (1904) clarified that the role of expert or supervisor is to get a student "to judge his own work critically, to find out for himself in what respects he has succeeded and in what failed, and to find the probable reasons for both failure and success" (p. 335). In this sense, students become responsible for their learning approach and have intrinsic motivation for making a change. They will also be able to get feedback from the teacher and other peers in order to make appropriate adjustment of attention and effort. By engaging in the process of authentic assessment, students can maintain social relationships through constructive communication. 
More importantly, whatever achievement students obtain, they would gain an insight into education by realizing that the actual value of learning is their intellectual growth. If a final product of academic performance were a poem, Montessori (2013) would argue, "the poem must spring from the soul of the poet, when he thinks neither of himself nor of the prize" ( $p$. 29). Students would get out of their comfort zones to determine what knowledge is beneficial not only to their own beings but also to the community. As a result, they would demonstrate what they have learned with full enthusiasm and interests. In other words, a practical method of evaluation is emotionally attached to learners' preferences and embraces meaningful learning outcomes.

Finally, authentic assessment supports the innovation of teaching and learning strategies as well as equitable evaluation. "Teaching to the tests" has been a common phrase in the era of high stakes testing when teachers have to be responsible for helping students earn high scores. Every year, American schools are busy preparing for the benchmark and state tests. The problem is that such tests are driving education back to traditional techniques of didactic teaching and rote learning. It is time to make an innovation, starting from changing the dominant, ineffective type of assessment.

With authentic assessment, teachers will have more time and energy for creative teaching strategies. They will be able to find all possible ways to help students learn and grow. At the same, students feel relaxed when they know clearly what and how they would be assessed.

Besides, Gardner (1999) appreciated the use of students' portfolios. He pointed out that assessment should match the sorts of intelligence that a child has, be appropriate with his developmental stage, and connect with some suggestions of future improvement. $\mathrm{He}$ recommended individual profiles for meeting these criteria. Therefore, this qualitative approach advocates equity in education as it recognizes each student with a unique capacity. It also notices students' diverse learning styles and preferences. Students are no longer labeled with a number of scores as their profiles reveal both strengths and weaknesses. Students would not fail when they are authentically assessed.

In the field of English language teaching and learning, there have been several, but not many, research on using authentic assessment to improve teaching efficacy and learning outcome. In their article, Ramiréz and Artunduaga (2018) presents the result of a qualitative action research study examining the effects of authentic tasks on a group of EFL learners' oral production. The learners' performance was assessed in real communicative situations, which makes them much more engaged and confident during the learning approach. Moreover, students became more reflective in their own oral production, and then they found out their own problems or weakness.

Aziz and Yusoff did two studies in 2015 and 2016 about improving writing skill process in the English language classroom. Both results show that using authentic assessment is beneficial and useful in helping students to write better. Similarly, Idham et al. (2015) aimed to find out four types of authentic assessment used by teachers at a high school in SMA Negeri I Bungku Tengah. 
Particularly, the highest percentage of use is performance assessment. Teacher observation was the second one to be used. The next type was portfolio assessment. Finally, selfassessment accounted for the lowest percentage. It was concluded that authentic assessment was applied effectively, yet the teachers should pay more attention to get students to evaluate their own work better.

Zaim and Moria (2017) did a survey to find out teachers' need on authentic assessment for writing skills of grade VIII. The results show that teachers need some types of evaluation such as writing samples, process writing, portfolio, performance assessment, journal, and project/exhibition. Some important topics are family, famous people, things in students' lives. In addition, the teachers need simple analytical scoring rubrics.

Suffice it to say, there is not much research on authentic assessment in the field of English language teaching and learning, especially in teaching writing skills. This paper, hence, gives a contribution to the library of research on this topic of assessment, then it may become a good source of literature for English teachers to reflect on their teaching strategies as well as the process of evaluation.

\section{METHODOLOGY}

This study focused on exploring the effects of authentic assessment during the students' writing process. The researcher applied Creswell's (2013) qualitative interpretive design to gather the data and make analyses. This type of research aims to get a deep understanding of the phenomena such as behavior, perception, motivation and experience. A writing process checklist was adapted from McKenzie \& Tompkins (1984). Being in the role of a teacher, the researcher instructed her students to go through step-by-step writing stages, as Gardner \& Johnson (1997) pointed out: Pre-writing-Rough draft-Reread-Share with peer reviserRevise-Editing-Final draft-Publishing.

Creswell (2009) stated, "a qualitative observation is when the researcher takes field notes on the behavior and activities of individuals at the research site" (p.239). Accordingly, the first set of data was the teacher's journal entries when she observed carefully the students' gradual improvement each time they completed a task as well as took notes of their problems during learning process. Another data involved a semi-structured interview with the questions adapted from Fahed Al-Seharni (2001) and Losardo \& Notari-Syverson (2007).

The study was conducted at Thai Nguyen University of Technology during the second semester of school year 2017-2018. Participants were 15 students in K53AP class (13 male and 02 female). With preliminary questions about their English study, they had their similar answers, which means that they were at elementary level when they enrolled in the Writing 1 course. Nearly half of them admitted that they did not spend much time practicing their writing as they did not know what and how to produce a piece of writing coherently, accurately, and emotionally. During the study, interactions between the teacher and the students were in the classroom and through emails. 


\section{FINDINGS AND DISCUSSION}

\section{Teacher's journal entries}

During the semester, the teacher kept taking notes about her students' activities, learning approach and attitudes in the writing course. She found out some topics that students are interested in. These topics are close to their living experiences, which genuinely motivates students to write and tell their own stories. The topics are in different fields such as culture, customs, holidays, family, personal interests, scientific issues/discoveries. Besides, what the teacher was more concerned with was the students' problems in writing practice, both in-class tasks and take-home assignments.

\section{Difficulties in Writing Practice;}

Nearly all students had problems in using vocabulary in their writing. The reason why they were afraid of some types of topics was their limited vocabulary, which made them hard to express what they wanted. Another issue that discouraged them from having good writing was grammar. Commonly, they found it easier to tell the teacher orally what ideas they liked, yet, in a paper, they needed to write down those ideas correctly in terms of grammatical issues and structures. Several students got long papers and plenty of ideas, but they used to make mistakes in grammar. This would lead to more work in self-check and peer-reviewed hours.

Half of the students could not apply writing theories effectively in their papers; for instance, they did not organize their ideas based on a certain of an organization like chronological organization, or logical division of ideas. They also found it hard to use linking words and give examples or experiential events, which could make their writings coherently and convincingly. Moreover, the teacher sorted out some problems during the writing process.

\section{Problems during the Writing Process;}

The writing stages was adapted from Gardner \& Johnson (1997): Pre-writing-Rough draftReread-Share with peer reviser-Revise-Editing-Final draft-Publishing. For the first step, the teacher encouraged her learners to brainstorm as many ideas as possible. Some students were eager to jot down many interesting topics, but others could not think of more than two or three ideas when they spent time free writing. Outlining is an essential step for a writer to scaffold his/her views logically, so the writer must arrange ideas in a way that is efficient enough to develop them in writing better. Thus, it was not easy for more than half of the students to make a good outline.

As for self-check work, it is normal for students not to be able to recognize all the mistakes in their own writings. In order to deal with this, the teacher suggested the students some possible ways to improve their writings, and then let them work more with peer revisers. They would feel less stressful to share their issues with their classmates. Sometimes, they could work in groups of three or four, and the group leader would inform the teacher of all the advantages and disadvantages during the period of task fulfillment. Emotionally, the teacher saw that her students collaborated well with one another. Although the students had difficulties in completing their papers correctly and coherently, they had positive attitude towards writing lessons. This made the teacher think of changes in assignment and assessment. Authentic assessment is a feasible strategy to be applied in writing skills when the teacher can be flexible in designing and choosing types of tests and methods of evaluation. 
Muller (2005) explained that the steps of designing authentic assessments are to determine the standard, to choose authentic tasks, to determine criteria of students' performance, and to make scoring rubric. The researcher conducted this study based on these steps. Students got weekly assignment of their writing tasks. In particular, as Wiggins (1990) asserted, "assessment is authentic when we directly examine student performance on worthy intellectual tasks" (p.1); therefore, the students took their opportunities to think critically about what they had to do each week. The assignment lasted five weeks and included the work as follows:

$>$ Week 1: Think of at least three topics that are connected with your real life. Among these three topics, choose the ONE you like best. Find and list different supporting sources (book, online sources, other people......) for the topic you like best.

$>$ Week 2: Make an outline of your topic. Think of the main ideas you are going to discuss.

$>$ Week 3: Write your first draft. Check your draft with peers and the teacher. Get feedback.

$>$ Week 4: Write the second draft. Peer-reviewed work. Teacher's consultation.

$>$ Week 5: Self-revision and check. Completion of the final paper. Teacher's overall comments on writing and task fulfillment.

The teacher designed a scoring rubric to assess students' final paper with three cs' criteria (clear, concise, and correct) of a good piece of writing, as Hatcher and Goddard (2005) noticed.

The second set of data was a semi-structured interview that helps the participants share their thoughts of authentic assessment.

\section{Semi-structured interview Questions}

At the end of the course, participants were asked two questions about the effect of authentic assessment on their writing skill development as well as the advantages and disadvantages of this evaluation. The following responses to the first questions were highly positive.

1. How does authentic assessment help you in your writing process?

Students confirmed that authentic assessment helped them much in improving their writing skills. In particular, when they got a step-by-step assignment, they could master the process of writing and had more time to arrange their ideas into a good organization.

- "I think authentic assessment is useful. It helps to improve my writing when we have step by step assignment for several weeks."

- "It helps me practice my skill well. I have a long time to do and modify"

Moreover, students felt happier when they could find more resources or referent materials to make their writings more persuasive and engaging to readers.

- "I have enough time to brainstorm and find information."

2. Based on your own writing practice, could you tell the advantages and/or disadvantages of authentic assessment?

When being asked about the advantage of assignment, the students clarified that they got to know how to create an essay from the first step to the last step of modification and completion. 
- "more time to think ideas for the topic; more time to write and correct mistake; get more information for the topic, after step-by-step, I improved my writing although I still have some mistakes..."

- "Know how to do good writing with an outline and logic organization."

- "Easy to understand for students."

- "Know how to make a complete essay."

However, some students said that they felt stressed when they spent much time doing all the steps of the assignment week by week.

- "Feel stressful about homework."

- "Long time through steps of assignment."

Thus, the teacher should care about students' attitudes when they engaged in different activities of authentic assessment. They might need more encouragement or some other hands-on activities for each step, which could exhilarate them more in a writing class.

From the findings, it is evident that authentic assessment has a good effect on students' writing skill development. Writing may no longer be a challenging course for English language learners when they know how to make their products of writing based on comprehensible instructions and steps in turn. They also had opportunities to self check their own writing products and got advice from the teacher and peers. Consequently, they became more active and responsible in their choices of topics and the whole work of assignment. Although causing some disadvantages, authentic assessment proves to be an effective strategy for teachers to evaluate students' outcomes. The teacher, in this case, had more experience with authentic assessment so she would be able to design more interesting activities to draw students' attention and stimulate their endeavor.

\section{CONCLUSION}

In conclusion, authentic assessment helps students to develop their cognitive abilities and makes them more active in learning as well as self-evaluation. In addition, it improves the quality of education with innovative pedagogy and fair assessment for all learners. Gardner (1999) reminded us, "the real obstacles to individual-centered education are not financial constraints or knowledge limitations, but rather questions of will" (p. 78). He asked us to strive to support each child, especially by evaluating the child's academic performance through a real-life, holistic process. From such a vantage point, the paper recommends the application of authentic assessment not only in writing classes but also in other courses of different language skills. Moreover, applying authentic assessment in current education requires patience and will from policymakers, curriculum leaders, and teachers to advocate successively for students' learning and to try to make assessment an opportunity for their forward steps into a successful future.

\section{References}

Al-Serhani, W. Fahed. (2007). The effect of portfolio assessment on the writing performance of EFL second school students in Saudi Arabia. (Taibah University, Saudi Arabia). Unpublished M.A thesis.

Ashford-Rowe, K., Herrington, J., \& Brown, C. (2014). Establishing the critical elements that determine authentic assessment. Assessment \& Evaluation in Higher Education. $39(2), 205-222$. 
Aziz, Noor bin A. Muhammad \& Yusoff, M. Nurahimah (2015). Using portfolio to assess Rural young learners' writing skills in English language classroom. The Malaysian Online Journal of Educational Science, 3(4), 46-54.

Aziz, Noor bin A. Muhammad \& Yusoff, M. Nurahimah (2016). Improving process writing with the use authentic assessment. International Journal of Evaluation and Research in Education, 5(3), 200-204.

Barkaoui, K. (2007). Teaching writing to second language learners: Some insights from theory and research. TESL Reporter, 40, 35-48.

Brown, D. (2004). Language assessment: Principles and classroom practices. New York: Longman.

Brown, D. F. \& Knowles, T. (2007). What every middle school teacher should know. (2 ${ }^{\text {nd }}$ ed.). Portsmouth, NH: Heinemann.

Creswell, J. W. (2009). Research design: Qualitative, quantitative and mixed methods approaches. Los Angeles, US: SAGE Publications.

Creswell, J. W. (2013). Qualitative inquiry and research design: Choosing among five approaches (3rd ed.). Los Angeles: SAGE Publications.

Cumming, J.J. \& Maxwell, G.S. (1999). Contextualizing authentic assessment. Assessment in Education: Principles, Policies, and Practices. 6(2), 177-194.

Dewey, J. (1904). The relation of theory to practice in education. Retrieved from http://people.ucsc.edu/ ktellez/dewey_relation.pdf

Eryaman, M. Y. \& Genc, S. (2010). Learning theories. In C. Kridel (Ed.), The Sage encyclopedia of curriculum studies (pp. 534-537). Thousand Oaks, CA: Sage.

Gardner, A. \& Johnson, D. (1997). Teaching personal experience narrative in the elementary and beyond. Flagstaff, AZ, Northern Arizona Writing Project Press.

Gardner, H. (1999). Intelligence reframed: Multiple intelligences for the 21st century. New York: Basic Books.

Gulikers, J. T. M. (2006). Authenticity in the eye of the beholder: Beliefs and perceptions of authentic assessment and the influence on student learning. Maastrict: Datawyse.

Hatcher D. \& Goddard, L. (2005). The writing process: A step by step approach for everyday writers. Landa Books: USA

Idham, F. Islami, Nadrun, Darmawan (2015). The use of authentic assessment in English writing skill to the eleventh grade students. E-Journal of English Language Teaching Society, 3(1), 1-13.

Jensen, E. (1996). Brain-based learning. Del Mar, CA: Turning Point Publishers.

Losardo, A. \& Syverson, A. Notari. (2001). Alternative approaches to assessing young children. Baltimore, MD: Paul H. Brookes

McKenzie, L. \& Tompkins, G. E. (1984). Evaluating students' writing: A process approach. Journal of Teaching Writing, 3(2), 201-212.

Montessori, M. (2013). A critical consideration of the new pedagogy in its relation to modern science. In Flinders, David J. \& Stephen J. Thornton. The curriculum studies reader (4th ed., pp. 19-31). New York: Routledge.

Moon, S. (2014, March 5). Positivism \& reflection. [PowerPoint sildes]. Retrieved from https://oc.okstate.edu/d21/le/content/997330/viewContent/3796007/View 
Mueller (2005). The authentic assessment toolbox: Enhancing student learning through online faculty development. Journal of Online Learning and Teaching, 1(1). Retrieved from http://jolt.merlot.org/documents/vol1 no1 mueller 001.pdf [15 October 2018].

Noguera (2013). Schools need more than the common core. The Nation. Retrieved from http://www.thenation.com/article/176130/schools-need-more-common-core\#

Puppin, L. (2007). A paradigm shift: From paper-and-pencils tests to performance-based assessment. English Teaching Forum, 45(4), 10-17.

Ramírez Ortiz, S. M. \& Artunduaga Cuéllar, M. T. (2018). Authentic tasks to foster oral production among English a foreign language learners. $H O W, 25(1), 51-68$. https://doi.org/10.19183/how.26.1.362.

Swaffield, S. (2011). Getting to the heart of authentic assessment. Assessment in Education: Principles, Policies, and Practices, 18(4), 433-449.

Thuy, T. V. \& Gloria, D. (2013). Authentic assessment for student learning: An ontological conceptualization. Educational Philosophy and Theory. Doi:10.1080/00131857.2013.795110

Wiggins, G. (1990). The case for authentic assessment. Practical Assessment, Research and Evaluation, 2(2). Retrieved from http://PAREonline.net/getvn.asp?v=2\&n=2 [15 October 2018].

Wiggins, G. P. (1993). Assessing student performance. San Francisco, CA: Jossey-Bass. Y. Suneetha (2014). Constructive classroom: A cognitive instructional strategy in ELT. Imanager's Journal on English Language Teaching, 4(1), 1-3.

Zaim, Refnaldi M. \& Moria, Elva (2017). Teachers' need for authentic assessment to assess writing skill at Grade VII of Junior High Schools in Teluk Kuantan. Advances in Social Science, Education and Humanities Research (ASSEHR), 110, 179-185.

\section{Acknowledgements}

I am thankful to Thai Nguyen University of Technology and University of Economics and Business Administration for providing grant to this research. 